\title{
半導体素子の生産過程で蓄積する転位の抑制に関する結晶塑性解析
}

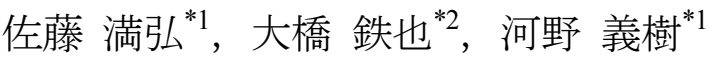

\section{Crystal plasticity analysis of the suppression of dislocation accumulation during the production process of semiconductor devices}

\author{
Michihiro SATO ${ }^{* 1}$, Tetsuya OHASHI ${ }^{* 2}$ and Yoshiki KAWANO *1 \\ ${ }^{* 1,{ }^{*}}$ Department of Mechanical Engineering, Kitami Institute of Technology \\ 165 Koen-cho, Kitami-shi, Hokkaido 090-8507, Japan
}

Received: 25 December 2019; Revised: 11 February 2020; Accepted: 24 March 2020

\begin{abstract}
High-density memories and high-speed CPUs are usually realized by reduction of the size of semiconductor cells in Large Scale Integrations (LSIs). Representative length scale of Ultra Large Scale Integration (ULSI) cells is going to be in nano-meter order. Dislocation accumulation during the production process in the electron channel of semiconductor device is one of the most serious problems. Dislocation accumulation has an enormous effect on the electronic state of the device. Therefore, the evaluation and suppression of dislocation accumulation are crucially important for the design and development of semiconductor device structure. In this study, we numerically analyze the suppression of dislocation accumulation in the shallow trench isolation type ULSI cells. Accumulation of dislocations is analyzed by employing a technique of crystal plasticity analysis and we evaluate the dislocation density distribution and total length of dislocations in the silicon substrate. Possibilities for the suppression of dislocation accumulation are discussed.
\end{abstract}

Keywords : ULSI, Shallow Trench Isolation, Dislocation, Crystal plasticity analysis

\section{1. 緒言}

情報機器におけるメモリーや演算チップは，半導体技術ロードマップに示されているように，半導体素子構造 の微細化と高集積化により高性能化が図られている. 現段階での素子の代表寸法は数十ナノメートルに達してお り，ナノスケール構造となる半導体素子の量産化に向けた生産プロセスの確立が急務である. しかしながら，こ のような超微細化された半導体に関して，従来行われてきた生産プロセスや材料を適用することが出来ず大きな 問題となっている。 その原因として，ナノスケールデバイスの生産過程で生ずる不均一な酸化膜の形成や異相界 面付近に生ずる結晶欠陥など原子レベルでの諸問題がある．結晶欠陥の中で特に転位の発生は，素子中のチャネ ルを移動する電子の状態に大きな影響を与え, リーク電流の増大や I-V 特性の悪化など, 正常なデバイス動作を 阻害する。このような半導体素子の生産過程において素子内部に生ずる転位の発生と蓄積は，製品の生産時の歩 留まりの低下をもたらし，量産化に大きく影響を与える.よって，生産過程で生ずる転位の発生・蓄積について の知見を得ることは重要であり, 次世代ナノスケールデバイスの量産化に向けたデバイス構造の設計・開発では, 転位発生部位の特定と構造の解明，特に転位発生の制御に関する検討が必要となる.

半導体素子間を浅い溝で分離する浅溝分離型（Shallow Trench Isolation type ; STI 型）構造は，最新のナノスケ ール半導体デバイスに広く用いられている。このような構造をもつ半導体素子の製造にはパターン転写，エッチ ング，薄膜積層などの多くのプロセスが関与するが，それらのプロセスの中で，浅溝が形成されたシリコン基板 を $1000^{\circ} \mathrm{C}$ 程度まで昇温したうえで溝領域に $\mathrm{SiO}_{2}$ を埋め込み, 室温まで降温するプロセスがある. $\mathrm{SiO}_{2}$ と $\mathrm{Si}_{\text {の 線 }}$

\footnotetext{
No.19-00457 [DOI:10.1299/transjsme.19-00457], J-STAGE Advance Publication date : 2 April, 2020

*1 正員，北見工業大学（干090-8507 北海道北見市公園町 165）

*2 正員，フェロー，北見工業大学

E-mail of corresponding author : sato@newton.mech.kitami-it.ac.jp
} 
膨張係数に違いがあるためにこの降温プロセスにおいて熱応力が発生し，それが Si 基板中に転位の発生・蓄積を もたらす可能性が生ずる.

このような転位の発生・蓄積を抑制する方法として, シリコン基板中にイオンを注入する手法がいくつか半導 体の製造方法についての特許（沼野他, 1997, 池田他, 2004, 石塚他, 2010, 五十嵐, 八高, 2010, 高橋, 2011）の中で 示され，何らかの不純物をシリコン基板内に注入することにより蓄積転位を抑制する効果があることが示されて いる. しかしこれらの公開情報では半導体素子構造や製造工程などそれぞれ異なり，イオン注入の位置や量，イ オン種なども個々の半導体製造装置と製造プロセスに密接に結びついていることから，イオン注入の効果につい て必ずしも一般性を持った理解が得られているわけではない. また多くの場合，上述の降温プロセスには塑性変 形がともなうために，素子の寸法や形状などを変更した場合に塑性変形がどのように変わって行くかを公開され た情報だけから予測することは難しい，したがって，新たな素子を設計する際には様々な実験を試行錯誤的に行 って構造の健全性を確保する必要がある. しかしながら, 実験による検証では 1 つの製品に対して数多くの実験 を行わなければならないことから, 多くの時間と手間を必要とする. 同様な問題に対して, 数值シミュレーショ ンにより転位の発生・蓄積についての情報が得られれば，半導体素子の開発・設計を効率化する手段として非常 に有効であると考えられる. 数值シミュレーションの手法として分子動力学や第 1 原理に基づくシミュレーショ ンを力学問題に適用した手法は, 微細な局所的構造の部位に対し有効であるが，素子構造の違いを対象とした場 合, 空間的, 時間的スケールが膨大となり計算コストを考えると現実的ではない. また, 半導体素子構造の変形 と力学応答に対する数值シミュレーションとして連続体力学をベースとした解析は適用することが可能であるが, 既存の連続体力学解析では塑性緩和による結晶中の転位の発生・蓄積について評価することはできない. これに 対し，これまで著者らのグループが構築してきたすべり変形に関する連続体力学解析（結晶塑性解析）による手 法では, 構造の変形に伴う塑性すべり, 転位の発生・運動・蓄積等を評価することが可能である，ただし，この 理論にはいくつかの仮説があり, 特に微細な寸法領域に生ずる現象では様々な「寸法効果」が考えられ, 解析結 果に影響を及ぼす可能性はあるが，本論文では「寸法効果」が無視できることを前提として検討を行う.そして， この手法を半導体素子における変形と転位の発生・蓄積問題に応用することで, 半導体素子内に発生蓄積する転 位についての数值シミュレーションを行ってきた. 半導体素子の生産過程における熱酸化膜形成時と降温プロセ ス時に素子内に発生・蓄積される転位のシミュレーション（Ohashi et al., 2003, Sato et al., 2006）では, 素子内の応 力集中が発生する 4 ケ所に転位が発生・蓄積されることを示し, その転位の密度と構造について検討した. また, 大きな温度依存性を有するシリコンの格子摩擦応力が転位の発生に大きく関与することから, シリコンの格子摩 擦応力に温度依存性を考慮したシミュレーション（Sato et al., 2007）を行い, 転位の発生は比較的素子温度が高温 時に生じることがわかり, 高温時のシリコンの格子摩擦応力と最終的に蓄積される転位の密度について検討した。 STI 型半導体素子の特徴であるトレンチ形状とゲート長の様々な寸法の半導体素子の生産過程における降温プロ セスと熱酸化膜形成時の転位発生シミュレーション（Sato et al., 2010, 佐藤他, 2016) を行い, 半導体素子の形状 の変化と蓄積転位について検討した。これまでのシミュレーションでは半導体素子のシリコン領域では純粋で一 様なシリコン材料と仮定し行ってきた。一方，半導体の電気的特性の発現には不純物ドーピングは欠かすことの できない生産工程の一つである，そこで，不純物ドーピングの影響を考慮したシミュレーション（佐藤他, 2009) を行った，不純物のドープにより，材料中の転位の易動度が変化することが実験的に示されて（Yonenaga et al., 2003)おり,この変化は巨視的には寸べり系の臨界分解せん断応力の変化をもたらすものと考えられることから, 解析においては局所的な不純物ドーピング領域の臨界分解せん断応力を変化させることで表現した．そして，不 純物ドーピングと蓄積される転位の密度とその領域について検討した。本研究では, 不純物ドーピングを考慮し たシミュレーションと同様にシリコンにイオン注入する効果をイオン注入した局所的な領域の臨界分解せん断応 力が変化するものと仮定し，イオン注入による転位抑制の可能性について解析を行ったものである. STI 型 ULSI 素子を対象とする構造とし, その製造過程で素子の一部分にイオンを注入することによって変化する塑性すべり や転位密度の空間的な分布を結晶塑性解析による数值シミュレーションを行うことで評価し, 半導体素子の生産 過程で蓄積する転位の抑制について検討する。 


\section{2. 解析モデル}

図 1 （a）にSTI 型 ULSI 素子が周期的に繰り返される構造を示す．図 1（b）に連続した構造より 1 周期分を取 り出し作製した解析モデルを示す. 半導体素子は(1) 〜 (6)領域から成り立つ. (1) $\mathrm{SiO}_{2}$ で埋め込んだトレンチ 部，(2)はゲート電極，(3)はソース・ドレイン電極，(4)と(5)はシリコン基板である. (5)の部分はシリコン基板内で 半導体素子の電気的な性能の発現に重要となる領域であり，素子機能形成領域と呼ぶことにする. (6)はオン注 入する領域でトレンチ底下部に左右対称に設けた．結晶方位は Si 基板法線方向が [100]，STI 構造のトレンチ方 向が $[01 \overline{1}]$ となるように作製した．この場合の結晶方位を表示したトンプソンの四面体を図 1 (c) に示寸．図 2 (a)，（b），(c) に解析に使用したモデルの構造と寸法を示す. トレンチ深さ $T_{d}=700 \mathrm{~nm}$ とし，ゲート長が $L_{g}=$ $62 \mathrm{~nm}, 45 \mathrm{~nm}, 32 \mathrm{~nm}$ のモデルである. $L_{g}=45 \mathrm{~nm}$ と $32 \mathrm{~nm}$ のモデルは $L_{g}=62 \mathrm{~nm}$ のモデルを横方向と奥行きを 縮小することによって作製した. イオン注入する領域(6の深さ $h$ を $h=30 \sim 120 \mathrm{~nm}$ の範囲とした. これらのモ デルは全て六面体八節点要素で要素分割を行い, 節点数 14280 , 要素数 10332 とした.

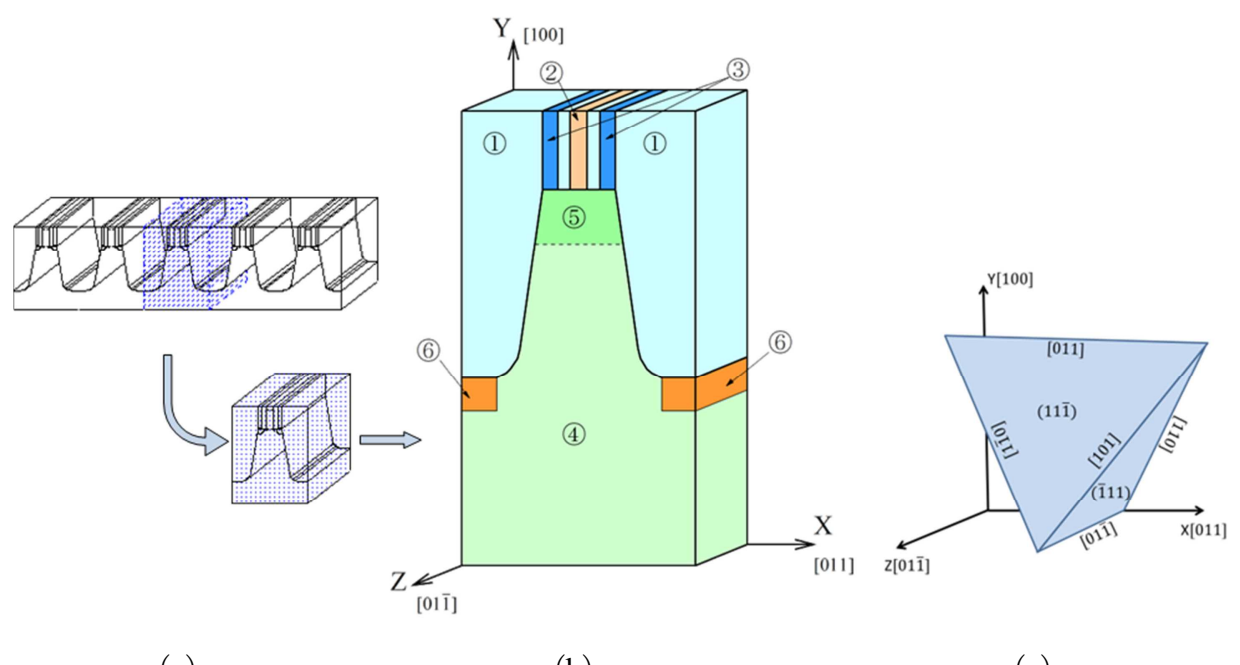

(a)

(b)

(c)

Fig. 1 (a) Schematic illustration of periodic structure of the STI type ULSI cells. (b) Structure of model employed for the crystal plasticity analysis. (c) Crystal orientation of the substrate depicted by Thompson's tetrahedron.

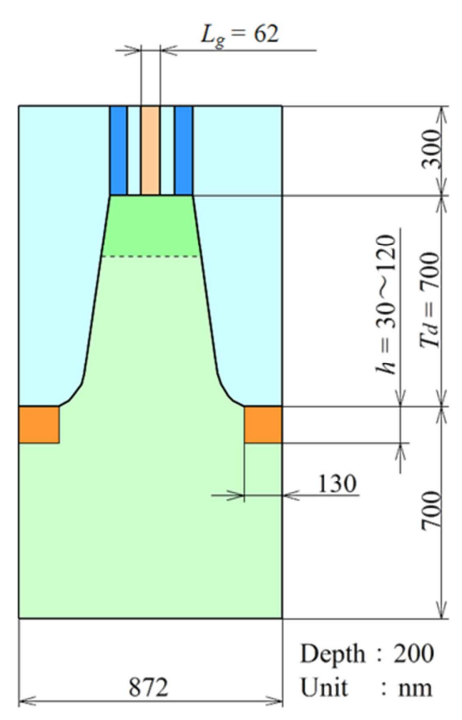

(a) $L_{g}=62 \mathrm{~nm}$

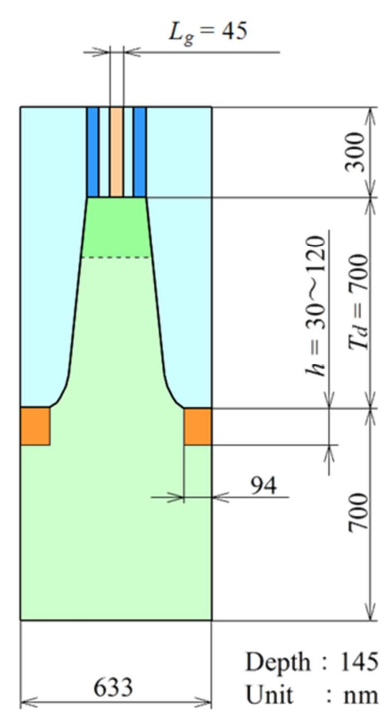

(b) $L_{g}=45 \mathrm{~nm}$

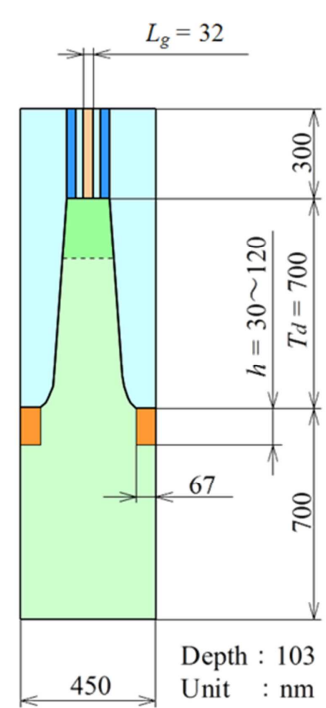

(c) $L_{g}=32 \mathrm{~nm}$

Fig. 2 Dimensions of the analysis models. 


\section{3. 結晶塑性解析}

解析にはひずみ勾配結晶塑性解析の手法を用いた。一般に材料中に蓄積される転位には，統計的に蓄積される 転位（SS 転位）と幾何学的に必要な転位（GN 転位）の 2 種類あるが，本研究では，GN 転位について解析を行 った，GN 転位は，あるすべり系に生じた塑性せん断ひずみの分布に空間的な勾配があったとき，そこに導入さ れなければならない転位であり，Ashby は，GN 転位密度が塑性せん断ひずみの勾配に比例する関係を一次元的 に式（1）で示した（Ashby, 1970）.

$$
\rho_{G} \cdot \tilde{b}=-\frac{\partial \gamma}{\partial \xi}
$$

ここで， $\rho_{G}$ は GN 転位密度， $\gamma$ は塑性せん断ひずみ， $\tilde{b}$ はバーガースベクトルの大きさ， $\xi$ はバーガース ベクトルに平行な方向である. 三次元空間における GN 転位は刃状転位とらせん転位から成り，すべり系番号を $n, \zeta$ をすべり面上でバーガースベクトルに垂直な方向とすると転位の刃状成分密度 $\rho_{G, \text { edge }}^{(n)}$ は式 (2), らせん成 分密度 $\rho_{G, \text { screw }}^{(n)}$ は式（3）で表される（Ohashi, 1997, 2005）.

$$
\begin{aligned}
& \rho_{G, \text { edge }}^{(n)}=-\frac{1}{\tilde{b}} \frac{\partial \gamma^{(n)}}{\partial \xi^{(n)}} \\
& \rho_{G, \text { screw }}^{(n)}=\frac{1}{\tilde{b}} \frac{\partial \gamma^{(n)}}{\partial \zeta^{(n)}}
\end{aligned}
$$

式 (2), (3) より GN 転位密度の大きさは式 (4) で, バーガースベクトルと転位線のなす角である特性角度 $\varphi$ は，式（5)，（6）で表される（Ohashi, 1997）.

$$
\begin{aligned}
& \left\|\rho_{G}^{(n)}\right\|=\sqrt{\left(\rho_{G, \text { edge }}^{(n)}\right)^{2}+\left(\rho_{G, \text { screw }}^{(n)}\right)^{2}} \\
& \sin \varphi=\frac{\rho_{G, \text { edge }}^{(n)}}{\left\|\rho_{G}^{(n)}\right\|} \\
& \cos \varphi=\frac{\rho_{G, \text { screw }}^{(n)}}{\left\|\rho_{G}^{(n)}\right\|}
\end{aligned}
$$

臨界分解せん断応力 $\theta^{(n)}$ は式（7）で表される修正 Bailey-Hirsh モデルを用いた（Ohashi, 1992）.

$$
\theta^{(n)}=\theta_{0}(T)+\sum_{m=1}^{12} \Omega^{(n m)} a \mu \widetilde{b} \sqrt{\rho_{s}^{(m)}}
$$

$n$ と $m$ はすべり系, 右辺第 1 項 $\theta_{0}(T)$ は格子摩擦応力であり, 転位の運動に対する摩擦応力を与える. これは 温度に強く依存する. 右辺第 2 項の $\Omega^{(n m)}$ は相互作用行列, $a$ は数值係数, $\mu$ はせん断弾性係数, $\rho_{s}^{(m)}$ はすべり 系 $m$ に蓄積した SS 転位密度である.SS 転位密度の発展は以下の式(8), 式(9)により求める. 


$$
\begin{aligned}
& \dot{\rho}_{s}^{(m)}=\frac{c \dot{\gamma}^{(m)}}{\tilde{b} L^{(m)}} \\
& L^{(m)}=\frac{c^{*}}{\sqrt{\sum_{m} \omega^{(m n)}\left(\rho_{S}^{(n)}+\left\|\rho_{G}^{(n)}\right\|\right)}}
\end{aligned}
$$

$c$ は 1 のオーダの数值係数, $\dot{\gamma}^{(m)}$ は塑性せん断ひずみ増分である. $L^{(m)}$ は転位の平均自由行程である. $\omega^{(m n)}$ は 重み行列， $c^{*}$ は材料パラメータで, SS 転位密度と GN 転位密度の関数として与えられる.

本解析では，式(7)を用いて臨界分解せん断応力を求めるが，半導体素子の製造に使われる Si ウエハーは高純 度 $\mathrm{Si}$ 材料であることからほぼ無転位の状態であり，式(7)における第 2 項の及ぼす影響は少ない．このことから 第 2 項の効果を取り入れる必要が無く, 数值係数の值を $a=1 \times 10^{-9}$ とし, 解析における臨界分解せん断応力は第 1 項に示寸格子摩擦応力にほぼ等しい值となるようにした。 ただし，解析では初期転位密度を一般的な $\mathrm{Si}$ ウエ八 一の許容值である $1 \times 10^{5} \mathrm{~cm}^{-2}$ とした.

数值解析には有限要素法をベースとした結晶塑性解析システムCLP (Ohashi, 1997, 2005) を用いた. モデルに生 ずる塑性すべり変形を解析し, 応力分布と結晶の 12 の\{111\}<110>すべり系に生ずる塑性せん断ひずみより式(4),

（5），（6）で与えられる GN 転位密度と特性角度を求め, GN 転位の分布と構造について解析する. STI 型素子 の $\mathrm{Z}$ 方向の長さは $\mathrm{X}$ 方向の繰り返し周期に比べ十分長いことから， $\mathrm{Z}$ 方向に垂直な前後両面上の節点は, $\mathrm{Z}$ 方 向に変位しないよう変位の拘束条件を与えた．また，X 軸に垂直な左右両側面には変形後においても X 軸に垂 直な平面を保ち変形するよう周期境界条件を与えた. 半導体素子の初期温度を $1000^{\circ} \mathrm{C} と し$, 温度降下にともなう 変形を解析した。

\section{4. 材料物性值}

図 1 （b）に示した(1)〜(3)の部分を $\mathrm{SiO}_{2}$ ，(4)，(5)および，(6)の部分を $\mathrm{Si}$ とした．表 1 に解析で用いた $\mathrm{SiO}_{2}$ と $\mathrm{Si}$ の弾性コンプライアンスと線膨張係数の值（半導体ハンドブック編纂委員会, 1977, 玉虫他, 1981）を示寸.

\section{$4 \cdot 1$ イオン注入のない Si の格子摩擦応力}

前項に述べたように, Si 中のすべり変形現象にすべり系の格子摩擦応力の大きさが重要な役割を果たす．しか し著者らが知る範囲において, Si の格子摩擦応力に関寸る実験值などは見つけられなかった. 一方, 図 3 は $800^{\circ} \mathrm{C}$ における転位の移動速度に関する実験結果である(Yonenaga et al., 2003)．すべり系の活動度は，すべり系に作用 する分解せん断応力（RSS と略する）によって決まる. 例えば，RSS の大きさによって転位の移動速度は大きく 変化し, CZ 成長した未ドープ材料では, RSS $=8 \mathrm{MPa}$ の時, 約 $3 \times 10^{-7} \mathrm{~m} / \mathrm{s}$ であり, RSS $=30 \mathrm{MPa}$ では, 約 $2 \times 10^{-6}$ $\mathrm{m} / \mathrm{s}$ である. 寸なわち, $800^{\circ} \mathrm{C}$ の Si にはクリープ変形が起こり, クリープ速度は作用する応力に依存する. しか し, STI 構造の溝領域(1) $\mathrm{SiO}_{2}$ を埋め込んだ後の冷却が比較的短時間で完了寸る場合, 低応力下でのクリープ現

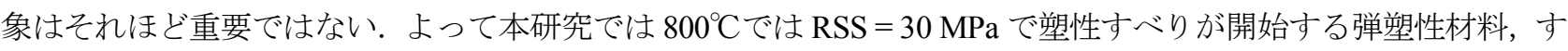
なわち， $800^{\circ} \mathrm{C}$ における臨界分解せん断応力（CRSS と略する）が $30 \mathrm{MPa}$ の材料に置き換えて検討をする.

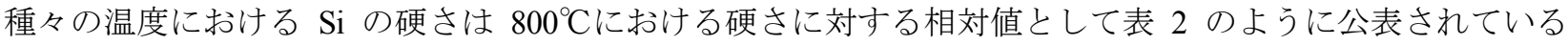
(INSPEC, 1988). 固体材料の硬さと塑性流動応力には比例関係があることが経験的に知られているので, 本研究 では $800^{\circ} \mathrm{C}$ の CRSS を $30 \mathrm{MPa}$ とし, 温度が室温まで低下寸るときの CRSS が表 3 のように変化するものと仮定し た.また, $800^{\circ} \mathrm{C}$ 以上 $1000^{\circ} \mathrm{C}$ ま゙は CRSS は $30 \mathrm{MPa}$ のまま変化しないものとした. 本解析では式（7）において $\mathrm{CRSS} \simeq$ 格子摩擦応力としていることから，Si の格子摩擦応力は表 3 に示寸值と同じ值を用いた. 
Table 1 Material data for $\mathrm{Si}$ and $\mathrm{SiO}_{2}$

(Semiconductors Handbook Compilation Committee ed., 1977), (Tamamushi et al., 1981).

\begin{tabular}{c|c|c|c|c}
\hline \hline Material & \multicolumn{3}{|c|}{ Elastic compliances } & $\begin{array}{c}\text { Thermal expansion coefficient } \\
{\left[10^{-11} \mathrm{~m}^{2} / \mathrm{N}\right]}\end{array}$ \\
\hline $\mathrm{SiO}_{2}$ (1) (3) $)$ & $S_{11}=1.3698$ & $S_{12}=-0.2327$ & $S_{44}=3.2051$ & $0.35 \times 10^{-6}$ \\
\hline $\mathrm{Si}$ (4), (5), (6) $)$ & $S_{11}=0.7685$ & $S_{12}=-0.2139$ & $S_{44}=1.2563$ & $2.50 \times 10^{-6}$ \\
\hline
\end{tabular}

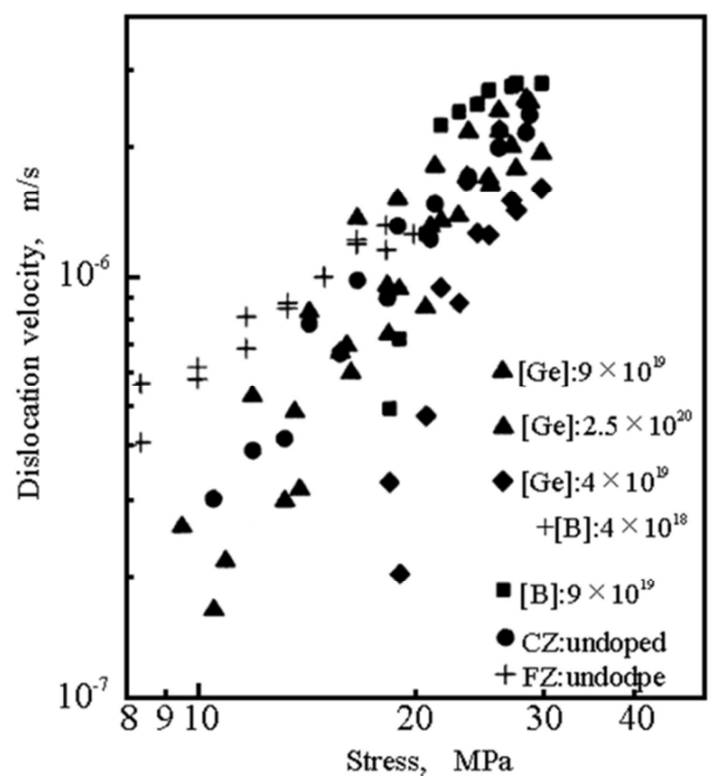

Fig. 3 Velocities of $60^{\circ}$ dislocations in various doped Si crystals at $800{ }^{\circ} \mathrm{C}$ as a function of the resolved shear stress. When the ions are doped in silicon, the mobility of dislocations changes (Yonenaga et al., 2003).

Table 2 Hot hardness values for silicon (INSPEC, 1988).

\begin{tabular}{l|cccccc}
\hline \hline Temperature $\left[{ }^{\circ} \mathrm{C}\right]$ & 24 & 100 & 200 & 400 & 600 & 800 \\
\hline Hot hardness value & 10.2 & 9.8 & 9.3 & 5.6 & 2.6 & 1.0 \\
\hline
\end{tabular}

Table 3 Critical resolved shear stress (CRSS) for Si used in the analyses.

\begin{tabular}{c|c|c|c|c|c|c|c}
\hline \hline Temperature $\left[{ }^{\circ} \mathrm{C}\right]$ & 24 & 100 & 200 & 400 & 600 & 800 & 1000 \\
\hline CRSS $[\mathrm{MPa}]$ & 306 & 294 & 279 & 168 & 78 & 30 & 30 \\
\hline
\end{tabular}

\section{$4 \cdot 2$ イオン注入を行った Si 領域の格子摩擦応力}

図 3 に示されているように，Siにイオンを注入すると転位の易動度が上昇する場合がある．注入するイオンの 種類によって易動度の変化の仕方は異なるが，易動度が上昇するようなイオンを部分的に注入すると，その箇所 の塑性すべり開始が早くなり, そこに転位が誘導される可能性がある (沼野他, 1997). 本解析では領域66格子摩 擦応力を式（10）により $\mathrm{Si}$ の值より減少させた值を用いた.

$$
\theta_{0}(T)^{\prime}=\beta \cdot \theta_{0}(T)
$$


$\theta_{0}(T)^{\prime}$ はイオン注入領域(6)格子摩擦応力, $\theta_{0}(T)$ は $\mathrm{Si}$ の格子摩擦応力, $\beta$ は係数である.イオン注入領域 の $\mathrm{Si}$ の格子摩擦応力が $\mathrm{Si}$ の值より減少する割合を $\beta$ で表した. 図 4 は領域(6)で用いる $\mathrm{Si}$ の格子摩擦応力と温度 との関係を青線で $\beta=0.9,0.8,0.7,0.6$ の場合について示した図である. 赤線はイオン注入のない $\mathrm{Si}$ の格子摩擦 応力 $(\beta=1.0)$ で, 表 3 に示した值と等しい.

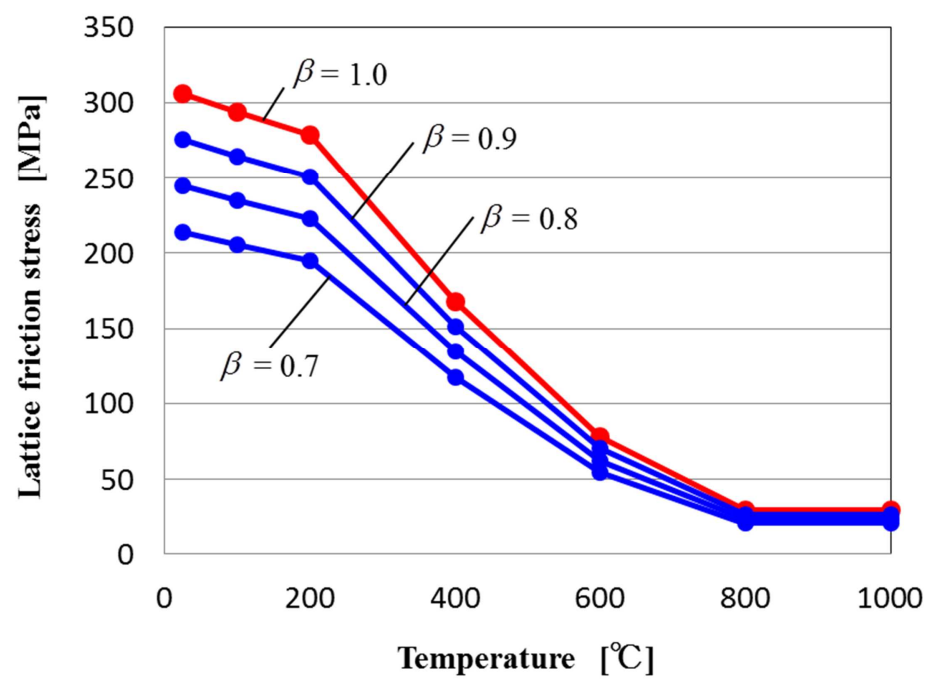

Fig. 4 Lattice friction stresses used in the analysis. The red line is the lattice friction stress of silicon, and the blue line is the lattice friction stress in the ion-doped region. As the value of $\beta$ decreases, the lattice friction stress decreases.

\section{5. 解析結果}

\section{$5 \cdot 1$ イオン注入のないモデルに蓄積される転位}

半導体素子の温度が $1000^{\circ} \mathrm{C}$ から降下寸ると, 素子機能形成領域の上部とトレンチ底の左右 4 ヶ所で応力集中が

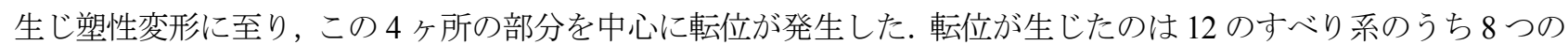
すべり系である. 発生した転位が形成する空間構造は，2 種類に分類される．表 4 に示す 4 つのすべり系で生じ る転位構造を $\mathrm{A}$ タイプ, 表 5 のものを B タイプとする. 図 5, 6 は図 2 (a) のモデルの半導体素子温度が $600{ }^{\circ} \mathrm{C} の$ ときに各すべり系に生じた転位構造を示した図である。これらの図では，式（4)，(5)，（6）より求めた GN 転位 密度と特性角度の值より各要素内に蓄積した GN 転位の長さと方向を求め, その線分を要素重心の箇所に表示し た (Ohashi, 2005)．表示した線が長いほど密度の高い転位が発生しており，線の方向は蓄積した転位線の方向と一 致する. 図 5 に示す $\mathrm{A}$ タイプの構造を形成する転位は $\mathrm{Si}$ 基板上部に発生し, 転位線がデバイスの素子分離溝に 平行で Z 軸方向に伸張する. 図 6 に示す B タイプの構造を形成する転位は素子機能形成領域とトレンチ底から発 生し，シリコン基板の内部方向に半ループ型に広がる。 A タイプの転位に比ベ B タイプの転位は転位密度が高 く, シリコン基板内部に広範囲で発生している。このことから, 蓄積される転位のほとんどは B タイプの転位で ある。

Table 4 Slip systems on which dislocations of A type accumulate.

\begin{tabular}{c|c|c}
\hline \hline No. & $\begin{array}{c}\text { Slip plane } \\
\text { normal direction }\end{array}$ & Slip direction \\
\hline 01 & $\left(\begin{array}{lll}1 & 1 & 1\end{array}\right)$ & {$\left[\begin{array}{llll}1 & \overline{1} & 0\end{array}\right]$} \\
03 & $\left(\begin{array}{lll}1 & 1 & 1\end{array}\right)$ & {$\left[\begin{array}{lll}1 & 0 & \overline{1}\end{array}\right]$} \\
04 & $\left(\begin{array}{lll}\overline{1} & 1 & 1\end{array}\right)$ & {$\left[\begin{array}{llll}1 & 1 & 0\end{array}\right]$} \\
06 & $\left(\begin{array}{lll}\overline{1} & 1 & 1\end{array}\right)$ & {$\left[\begin{array}{lll}1 & 0 & 1\end{array}\right]$} \\
\hline
\end{tabular}

Table 5 Slip systems on which dislocations of B type accumulate.

\begin{tabular}{c|c|c}
\hline \hline No. & $\begin{array}{c}\text { Slip plane } \\
\text { normal direction }\end{array}$ & Slip direction \\
\hline 07 & $\left(\begin{array}{llll}1 & 1 & \overline{1}\end{array}\right)$ & {$\left[\begin{array}{lll}1 & \overline{1} & 0\end{array}\right]$} \\
09 & $\left(\begin{array}{llll}1 & 1 & \overline{1}\end{array}\right)$ & {$\left[\begin{array}{lll}1 & 0 & 1\end{array}\right]$} \\
10 & $\left(\begin{array}{llll}1 & \overline{1} & 1\end{array}\right)$ & {$\left[\begin{array}{llll}1 & 1 & 0\end{array}\right]$} \\
12 & $\left(\begin{array}{llll}1 & \overline{1} & 1\end{array}\right)$ & {$\left[\begin{array}{lll}1 & 0 & \overline{1}\end{array}\right]$} \\
\hline
\end{tabular}




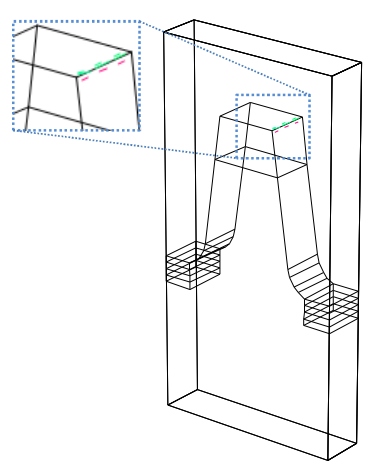

No.01 slip system

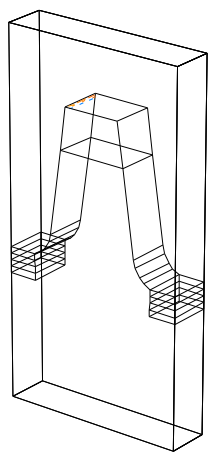

No.04 slip system

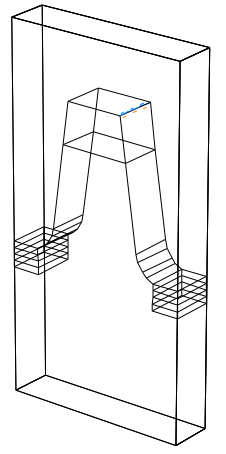

No.03 slip system

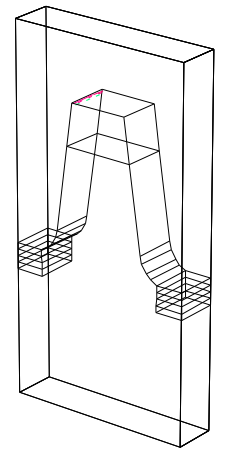

No.06 slip system

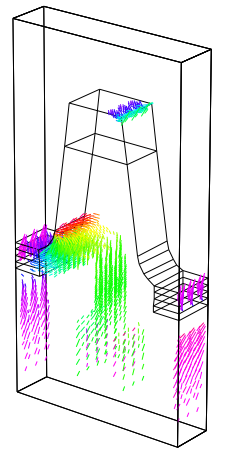

No.07 slip system

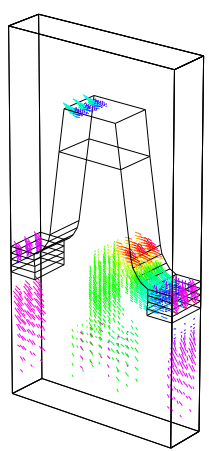

No.10 slip system

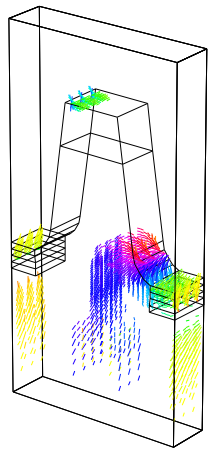

No.09 slip system

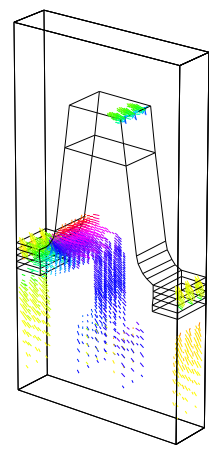

No.12 slip system
Fig. 5 GN dislocations which accumulate on the No.01, No.03,No.04 and No.06 slip systems, respectively. The colored line is the accumulated dislocation, and the longer the line, the higher density of dislocation.
Fig. 6 GN dislocations which accumulate on the No.07, No.09,No10 and No12 slip systems, respectively. The colored line is the accumulated dislocation, and the longer the line, the higher density of dislocation.

素子内に蓄積する転位の量を以下のように評価した。 寸なわち, 各有限要素に生じた GN 転位密度にその要素 体積を乗ずることで，その要素内の転位線長が得られる， $n$ をすべり系番号とすると，素子機能形成領域内の要 素の $n$ 番すべり系での転位線長の合計 $\left(t l d{ }^{(n)}\right)$ は式（11）で得られる. ただし， $v$ を要素体積， $i$ を素子機能形 成領域内の要素番号とする. また，12 すべり系における素子機能形成領域内の要素の転位線長を全て足し合わせ た総転位線長（TLD） は式（12）で得られる.

$$
\begin{aligned}
& t l d^{(n)}=\sum_{i}\left(\left\|\rho_{G}^{(n)}\right\|_{i} \times v_{i}\right) \\
& T L D=\sum_{n=1}^{12} t l d^{(n)}
\end{aligned}
$$

図 7 は図 2 (a) のモデルにおける半導体素子温度と式（12）で評価した総転位線長 $T L D$ との関係である. TLD は $850^{\circ} \mathrm{C}$ から $800^{\circ} \mathrm{C}$ にかけて急激に増加し， $650^{\circ} \mathrm{C}$ 以下の温度ではほとんど変化しないことから，モデルの泠却過 程において $850^{\circ} \mathrm{C}$ 以降で比較的短時間で塑性変形が生じていると考えられる.このことから SS 転位の増減に伴う 変形履歴（式 7 第 2 項）は関与せず, SS 転位密度も初期転位密度として与えた值 $1 \times 10^{5} \mathrm{~cm}^{-2}$ から変化が無かっ た．素子内にはすべり変形によって生ずる $\mathrm{GN}$ 転位が蓄積される，以上より，解析結果は全て GN 転位について 示し，変形が終了した半導体素子温度が $600^{\circ} \mathrm{C}$ 場合とした. 


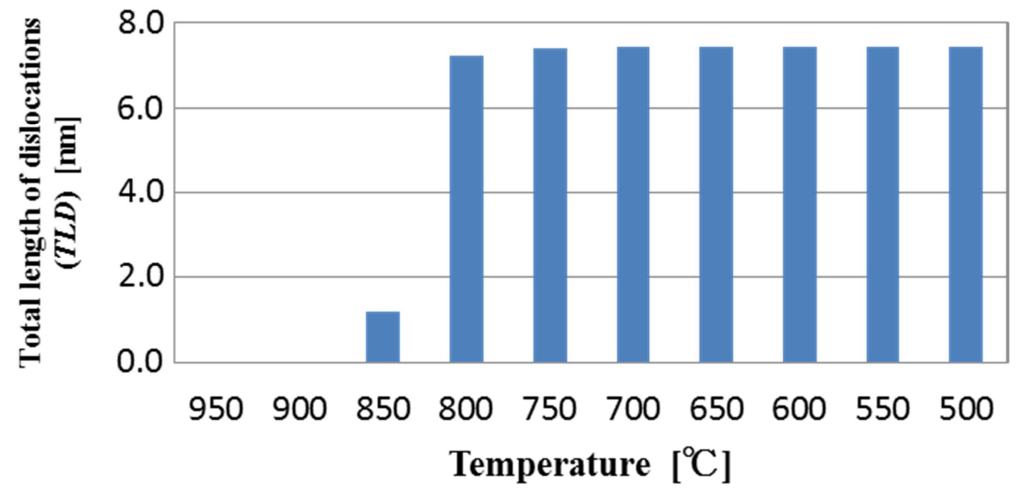

Fig. 7 Total length of dislocations $(T L D)$ as a function of the temperature of cells. The amount of dislocations accumulated in the device. Dislocations accumulate rapidly from $850^{\circ} \mathrm{C}$ to $800^{\circ} \mathrm{C}$.

\section{$5 \cdot 2$ イオン注入を行ったモデルに蓄積される転位}

図 8 は図 2 (a) のモデルにおける領域66格子摩擦応力の減少割合 $\beta$ と No.07 すべり系での転位線長の合計 $\left(t l d^{(07)}\right)$ に関する結果である. 領域(6)の深さ $h$ が (a) $h=30 \mathrm{~nm}, \quad$ (b) $h=60 \mathrm{~nm}, \quad$ (c) $h=90 \mathrm{~nm}, \quad(\mathrm{~d}) h=120 \mathrm{~nm}$ のそれぞれの場合について示した. 参考の為, 各図中の左端にイオン注入のない場合 $(\beta=1.00)$ の結果を示した. どの場合も $\beta$ が減少すると, $t l d^{(07)}$ も減少し, (b), (c), (d) においては $\beta=0.70$ で 0 となり, 転位が生じなく なる. また，これらの $h$ の異なる 4 つのモデルともに, tld ${ }^{(07)}$ の減少のしかたに大きな違いはない. トレンチ底 下部のごく薄い箇所に $\beta$ が十分小さな值となるようなイオンを注入することで素子機能形成領域に生ずる転位 を抑制することが可能であることがわかる。

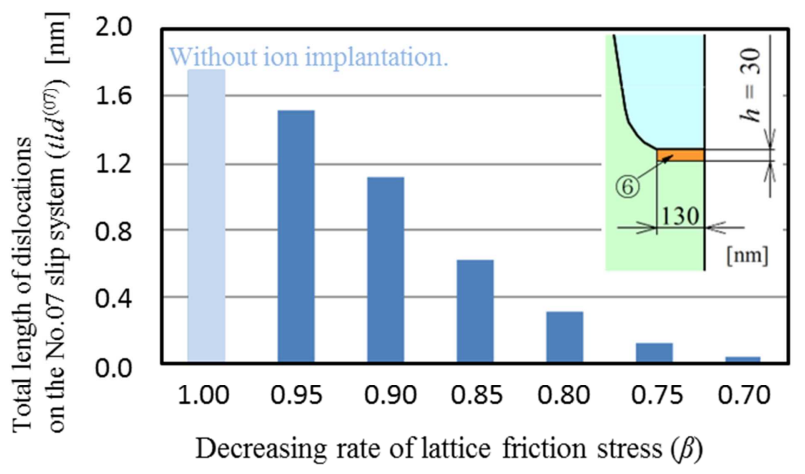

(a) $h=30 \mathrm{~nm}$

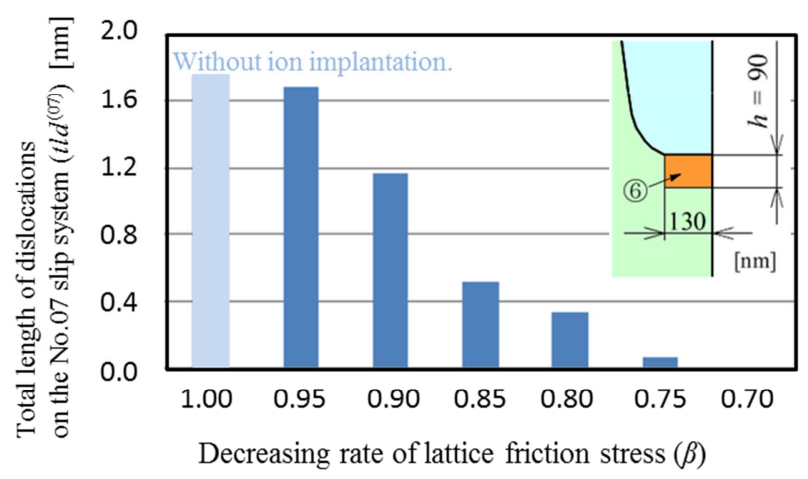

(c) $h=90 \mathrm{~nm}$

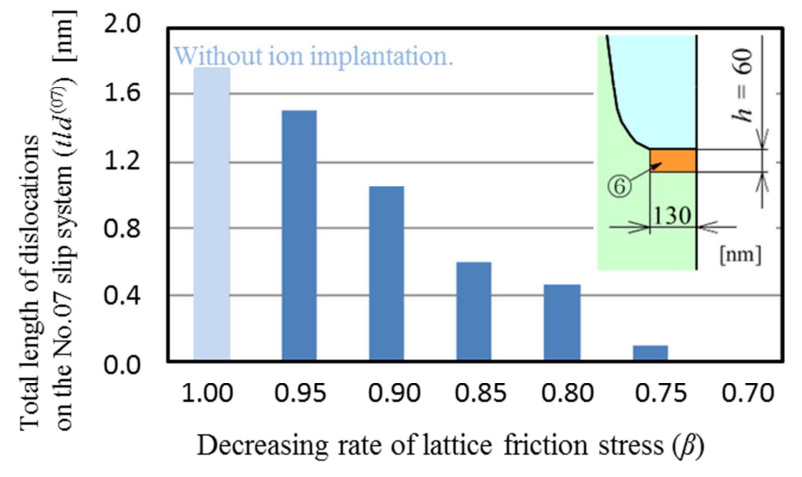

(b) $h=60 \mathrm{~nm}$

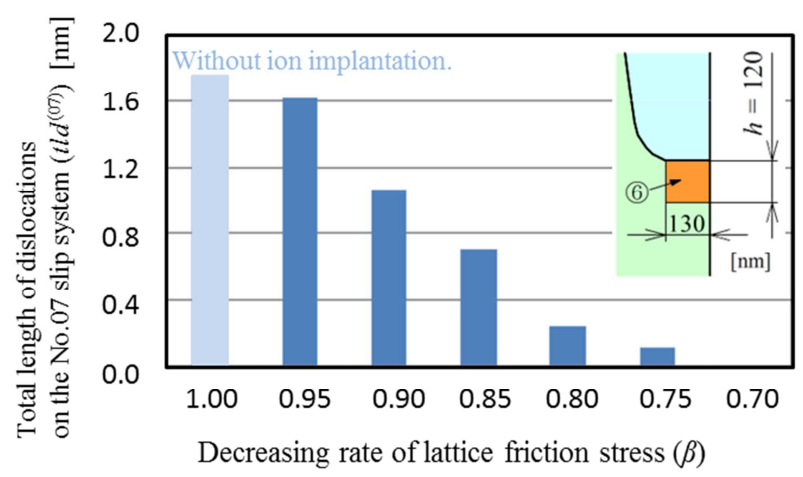

(d) $h=120 \mathrm{~nm}$

Fig. 8 Total length of dislocations on the No.07 slip system $\left(t l d^{(07)}\right)$ as a function of the decreasing rate of lattice friction stress $(\beta)$. When the ions are doped at the bottom of the trench, the dislocations accumulated on the top of the silicon substrate are decreased. 
図 9 は図 8 (b) で示した $h=60 \mathrm{~nm}$ のモデルについて, すべり系 No.07 の転位構造を示した図である. 左端の 図はイオン注入のない場合である。素子機能形成領域の右肩部に生じた転位は, $\beta$ の減少によって, 次第に発生 領域が減少し， $\beta=0.7$ で転位が生じなくなる. 図 10 は各すべり系の GN 転位密度を全て足し合わせた密度分布 である。 $\beta$ が減少すると領域(6)高密度の転位が生ずるようになるが，素子機能形成領域上部に生じた転位はそ の発生領域が次第に小さくなり, $\beta=0.7$ で転位が消失している.

通常イオン注入のない場合, STI 型構造の半導体素子は生産過程における降温プロセスにおいて, 主に $\mathrm{SiO}_{2}$ で 形成される上部構造と Si で形成される下部構造との異相界面で熱忘力が発生し, その構造上素子機能形成領域の 上部とトレンチ底の左右 4 ヶ所に応力集中が生じることから, 図 5, 図 6 に示寸ように, この 4 ヶ所に集中して 転位が発生し蓄積される. 転位の発生に関して本研究では Schmid 則を仮定し, すべり系に加わるせん断応力 RSS が, 対象とするす心゙り系が働くのに必要なせん断応力 CRSS を超えた時に, そのすべり系が活動し, 転位の発生 と蓄積をもたらす.イオン注入領域にイオンを注入することで $\mathrm{Si}$ の格子摩擦応力が低下寸る場合 $(\beta<1.0)$ に は，その部分の CRSS が低下し，局所的な塑性すべりが最も早く発生し，その部分に転位が誘導される. その結 果, 素子機能形成領域の上部 2 ヶ所に生じた応力集中が緩和され, その部分のすべり系に作用する RSS が減少し, その部分の CRSS を超えなくなり，すべり変形が生じなくなる．このように意図的にトレンチ底に塑性すべりを 誘発させることで, 図 10 に示すようにトレンチ底の CRSS が低下寸ることによって, 転位密度は非常に高い值と なるが，素子機能形成領域の上部 2 ケ所では，RSS の減少をもたらし，転位発生を抑制する効果をもたらす。

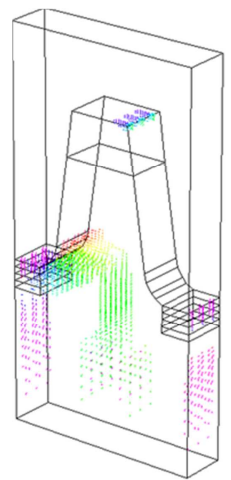

Without ion implantation

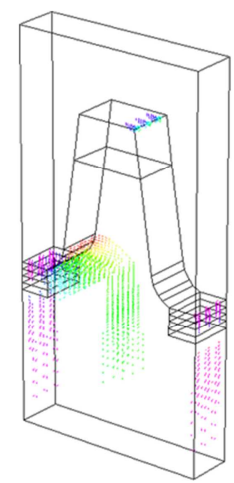

$\beta=0.9$

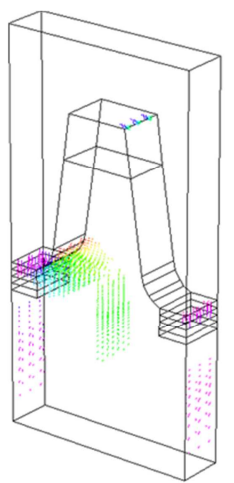

$\beta=0.8$

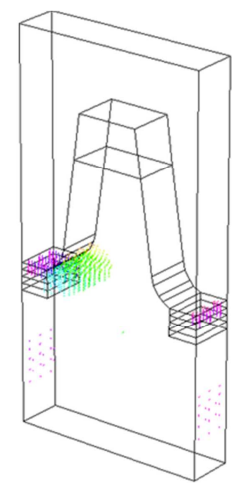

$\beta=0.7$

Fig. 9 GN dislocations which accumulate on the No.07 slip system in the model of Fig.2 (a) $\left(L_{g}=62 \mathrm{~nm}\right)$. The colored line is the accumulated dislocation. When $\beta$ reduces, the dislocation accumulated on the top of the silicon substrate are decreases.

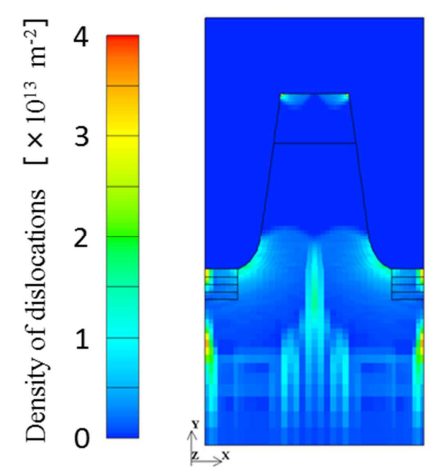

Without ion implantation

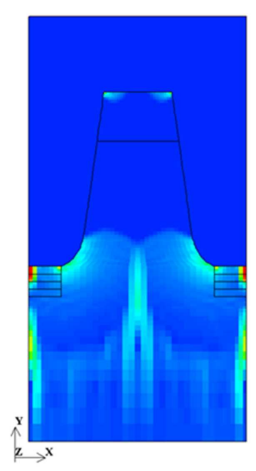

$\beta=0.9$

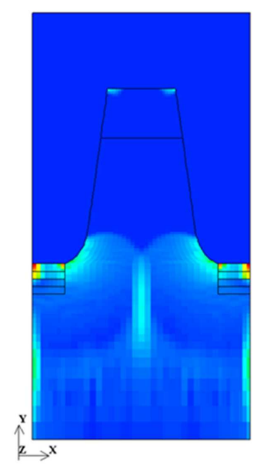

$\beta=0.8$

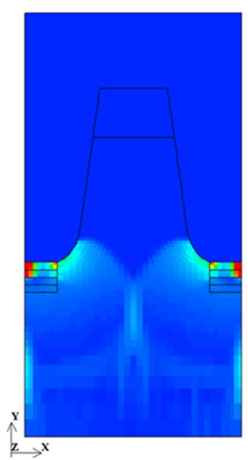

$\beta=0.7$

Fig. 10 Distribution of the GN dislocation density in the model of Fig.2 (a) ( $L_{g}=62 \mathrm{~nm}$ ). When $\beta$ reduces, high-density dislocations accumulate in the ion-doped region. On the other hand, dislocations accumulated on the top of the silicon substrate are decreases. 
図 11 は図 $2(\mathrm{a})$ ，(b)，(c) に示したゲート長が $L_{g}=62 \mathrm{~nm}, 45 \mathrm{~nm}, 32 \mathrm{~nm}$ で $h=60 \mathrm{~nm}$ のモデルについて総転 位線長 $T L D$ と $\beta$ との関係を示した図である. 左端は各モデルでイオン注入のない場合の結果である. ゲート長が 異なっても $\beta$ が減少すると TLD が減少し，転位の発生を抑制していることがわかる．半導体素子が微細化され ると発生する転位の密度が高くなる (Ohashi et al., 2003, Sato et al., 2010) ことから $L_{g}=32 \mathrm{~nm}$ のモデルでは $\beta=0.7$ でも転位が生じているが, $\beta=0.6$ で消失している.

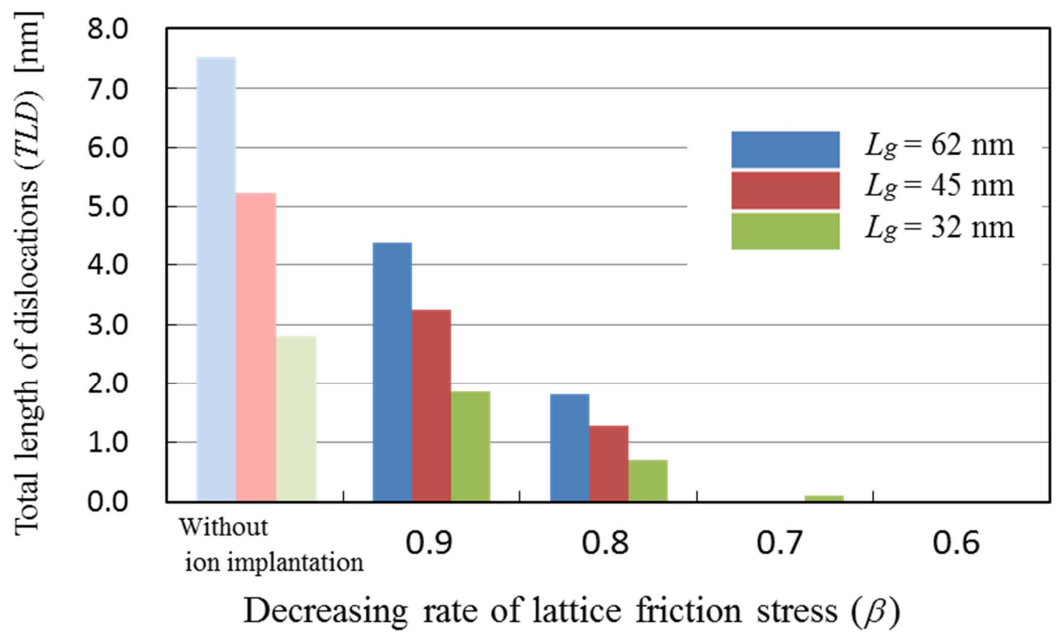

Fig. 11 Total length of dislocations (TLD) as a function of the decreasing rate of lattice friction stress $(\beta)$. This shows the amount of dislocations accumulated on the top of the silicon substrate of a semiconductor device when the gate length is $L_{g}=62 \mathrm{~nm}$ (blue), $L_{g}=45 \mathrm{~nm}$ (red), and $L_{g}=32 \mathrm{~nm}$ (green). Even if the element size is different, when $\beta$ reduces, the dislocations accumulated on the top of the silicon substrate are decreases.

図 12, 図 13 は図 2(b), (c) に示したゲート長 $L_{g}=45 \mathrm{~nm}, 32 \mathrm{~nm}$ で $h=60 \mathrm{~nm}$ のモデルの各すべり系の GN 転位 密度を全て足し合わせた密度分布である. 図 10 に示したゲート長 $L_{g}=62 \mathrm{~nm}$ の場合と同様に $\beta$ を減少させると 領域(6の CRSS が低下することで塑性すべり開始が早まり高密度の転位が生ずる．このようにトレンチ底下部に 設置した領域(6で蓄積された高密度の転位は半導体の電気的特性へ直接影響寸ることは極めて低いと考えられる。 さらにこの効果が素子機能形成領域上部での RSS の減少をもたらすことで, $L_{g}=45 \mathrm{~nm}$ では $\beta=0.7$ で, $L_{g}=32 \mathrm{~nm}$ では $\beta=0.6$ で転位は生じなくなる.このようにゲート長が短くなり微細化された素子構造においても転位を抑 制する効果をもたらす.

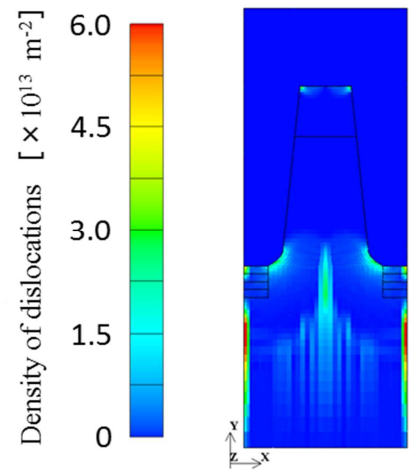
Without ion implantation

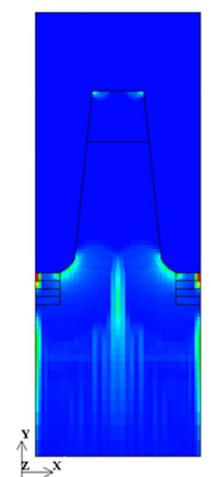

$\beta=0.9$

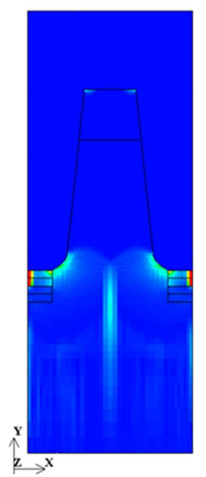

$\beta=0.8$

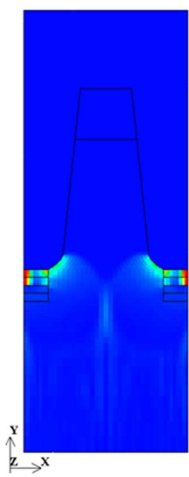

$\beta=0.7$

Fig.12 Distribution of the GN dislocation density in the model of Fig.2 (b) ( $\left.L_{g}=45 \mathrm{~nm}\right)$. Even when the gate length is $L_{g}=45 \mathrm{~nm}$, when $\beta$ decreases, high-density dislocations accumulate in the ion-doped region. On the other hand, dislocations accumulated on the top of the silicon substrate are decreases. 


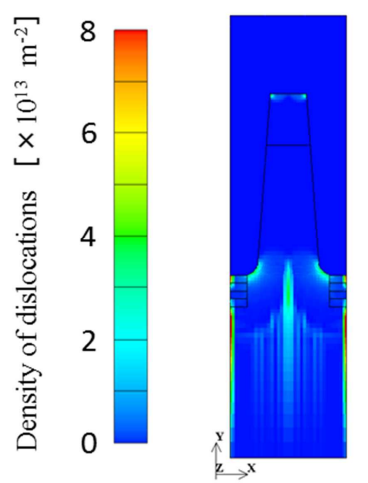

Without ion implantation

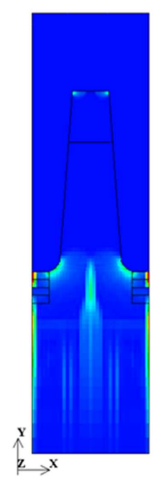

$\beta=0.9$

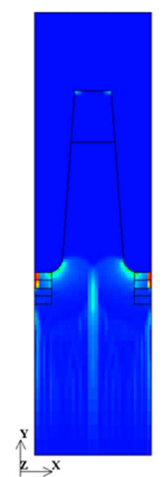

$\beta=0.8$

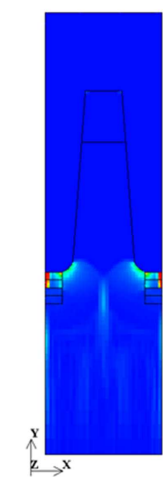

$\beta=0.7$

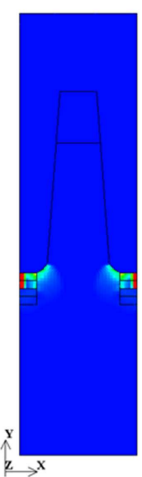

$\beta=0.6$

Fig. 13 Distribution of the GN dislocation density in the model of Fig.2 (c) $\left(L_{g}=32 \mathrm{~nm}\right)$. Even when the gate length is $L_{g}=32 \mathrm{~nm}$, when $\beta$ decreases, high-density dislocations accumulate in the ion-doped region. On the other hand, dislocations accumulated on the top of the silicon substrate are decreases.

\section{6. 結 言}

半導体素子内部の転位は生産過程の一つである降温プロセスにおいて塑性変形が生じ，素子内部に発生・蓄積 する．このような転位に対してシリコン基板中にイオンを注入し，素子機能形成領域に生ずる転位を抑制する手 法がある．この現象を結晶塑性解析による数值シミュレーションで再現した．結晶塑性解析では素子内に生ずる 塑性すべり変形を解析し，発生する転位の密度を求め，その分布と構造を得ることができる．また，塑性変形に 大きく影響する素子の形状・寸法と材料物性值が数值計算のパラメータとなっており，半導体素子の構造の変化 や内部の部分的な材料物性值の変化による転位蓄積への影響を十分評価することが可能である. 得られた結果を 以下に示す.

1. 本解析では $\mathrm{Si}$ 基板内にイオンを注入する効果をイオン注入部の格子摩擦応力を $\mathrm{Si}$ の值より減少させること により表現した。本手法により，イオン注入法による転位抑制と同様な現象を数值シミュレーションで再現 することが可能である。

2. ゲート長の異なる解析モデルのトレンチ底下部にイオンを注入する領域を設置し, その部分の格子摩擦応力 の值と素子機能形成領域に蓄積される転位の抑制について検討した．ゲート長が異なってもトレンチ底下部 のごく薄い領域にイオン注入することで，転位の発生・蓄積を抑制できる可能性を示唆している.

3. 結晶塑性解析による本シミュレーションは半導体素子の構造やイオンを注入する領域の様々な変更に対応 し，素子構造の設計段階で転位抑制の効果について評価と検討を行うことができる. 設計・開発の効率化に 有効な手段である.

\section{文献}

Ashby, M. F., The deformation of plastically non-homogeneous materials, Philosophical Magazine, Vol. 21 (1970), pp.399-424.

五十嵐信行，八高公一，半導体装置及びその製造方法，特開 2010-141184 (2010).

池田聡, 鎌田浩, 倉知郁生, MOS トランジスタの製造方法, 特開 2004-128388 (2004).

INSPEC, Properties of Silicon, EMIS data reviews series, No.4 (1988), p. 22.

石塚典男，太田裕之，木村泰広，半導体装置およびその製造方法，特開 2010-135553 (2010).

沼野正訓，土屋憲彦，久保田裕康，埋込素子分離基板およびその製造方法，特開平 9-69609 (1997).

Ohashi, T., Suppression of dislocation accumulation in GaAs film on Si substrate by combination of impurity doping and selective area growth, Journal of Materials Research, Vol. 7, No. 11 (1992), pp.3032-3038. 
Ohashi, T., Finite-element analysis of plastic slip and evolution of geometrical necessary dislocations in Fcc crystals, Philosophical Magazine Letters, Vol. 75 (1997), pp.51-57.

Ohashi, T., Sato, M., Maruizumi, T. and Kitagawa, I., Simulation of dislocation accumulation in ULSI cells with STI structure, Applied Surface Science, Vol. 216 (2003), pp.340-346.

Ohashi, T., Crystal plasticity analysis of dislocation emission from micro voids, International Journal Plasticity, Vol.21 (2005), pp.2071-2088.

Sato, M., Ohashi, T., Maruizumi, T. and Kitagawa, I., Crystal plasticity analysis of thermal deformation and dislocation accumulation in ULSI cells, Key Engineering Materials, Vol. 324-325 (2006), pp.1035-1038.

Sato, M., Ohashi, T., Maruizumi, T. and Kitagawa, I., Crystal plasticity analysis of dislocation accumulation in ULSI cells with consideration of temperature dependence of the lattice friction stress for silicon, Key Engineering Materials, Vol. 340-341 (2007), pp.199-204.

佐藤満弘，大橋鉄也，丸泉玩也，北川功，不純物がドープされた ULSI セルに生ずる転位の結晶塑性解析，日本機 械学会論文集 A 編, Vol. 75, No. 756 (2009), pp.121-126.

Sato, M., Ohashi, T., Aikawa, K., Maruizumi, T. and Kitagawa, I., Simulation of dislocation accumulation in ULSI cells of reduced gate length, Materials Science Forum, Vol. 654-656 (2010), pp.1682-1685.

佐藤満弘, 大橋鉄也，及川烹，丸泉玩也，ULSI 素子内の熱酸化膜形成時に生ずる転位の蓄積シミュレーション， 日本機械学会論文集，Vol. 82, No. 833 (2016), DOI:10.1299/transjsme.15-00457.

半導体ハンドブック編纂委員会, 半導体ハンドブック(1977), p.135, オーム社.

高橋邦方, 炭化珪素半導体素子及びその製造方法, 特開 2011-3825 (2011).

玉虫文一，富山小太郎，小谷正雄，安藤鋭郎，高橋秀俊，久保亮五，長倉三郎，井上敏，岩波理化学辞典第 3 版 (1981), p.1068, 岩波書店.

Yonenaga, I., Taishi, T., Huang, X. and Hoshikawa, K., Dynamic characteristics of dislocations in Ge-doped and (Ge+B) codoped silicon, Journal of Applied Physics, Vol. 93, No.1 (2003), pp.265-269.

\section{References}

Ashby, M. F., The deformation of plastically non-homogeneous materials, Philosophical Magazine, Vol. 21 (1970), pp.399-424.

Igarashi, N. and Yataka, K., Semiconductor device and its manufacturing method, Japanese patent disclosure H2010-141184 (2010) (in Japanese).

Ikeda, S., Kamata, H. and Kurati, I., Manufacturing method of the MOS transistor, Japanese patent disclosure H2004-128388 (2004) (in Japanese).

INSPEC, Properties of Silicon, EMIS data reviews series, No.4 (1988), p. 22.

Ishizuka, N., Outa, H. and Kimura, K., Semiconductor device and its manufacturing method, Japanese patent disclosure H2010-135553 (2010) (in Japanese).

Numano, M., Tutiya, N. and Kubota, H., Embedding element isolation substrate and its manufacturing method, Japanese patent disclosure H9-69609 (1997) (in Japanese).

Ohashi, T., Suppression of dislocation accumulation in GaAs film on Si substrate by combination of impurity doping and selective area growth, Journal of Materials Research, Vol. 7, No. 11 (1992), pp.3032-3038.

Ohashi, T., Finite-element analysis of plastic slip and evolution of geometrical necessary dislocations in Fcc crystals, Philosophical Magazine Letters, Vol. 75 (1997), pp.51-57.

Ohashi, T., Sato, M., Maruizumi, T. and Kitagawa, I., Simulation of dislocation accumulation in ULSI cells with STI structure, Applied Surface Science, Vol. 216 (2003), pp.340-346.

Ohashi, T., Crystal plasticity analysis of dislocation emission from micro voids, International Journal Plasticity, Vol. 21 (2005), pp.2071-2088.

Sato, M., Ohashi, T., Maruizumi, T. and Kitagawa, I., Crystal plasticity analysis of thermal deformation and dislocation accumulation in ULSI cells, Key Engineering Materials, Vol. 324-325 (2006), pp.1035-1038.

Sato, M., Ohashi, T., Maruizumi, T. and Kitagawa, I., Crystal plasticity analysis of dislocation accumulation in ULSI cells with consideration of temperature dependence of the lattice friction stress for silicon, Key Engineering Materials, Vol. 340-341 (2007), pp.199-204. 
Sato, M., Ohashi, T., Maruizumi, T. and Kitagawa, I., Crystal plasticity analysis of dislocation accumulation in impurity doped-ULSI cells, Transactions of the Japan Society of Mechanical Engineers, Series A, Vol. 75, No. 756 (2009), pp.121-126 (in Japanese).

Sato, M., Ohashi, T., Aikawa, K., Maruizumi, T. and Kitagawa, I., Simulation of dislocation accumulation in ULSI cells of reduced gate length, Materials Science Forum, Vol. 654-656 (2010), pp.1682-1685.

Sato, M., Ohashi, T., Oikawa, T. and Maruizumi, T., Simulation of dislocation accumulation in ULSI cells during the formation of thermal oxide film, Transactions of the JSME (in Japanese), Vol. 82, No. 833 (2016), DOI:10.1299/transjsme.15-00457.

Semiconductors Handbook Compilation Committee ed., Semiconductors Handbook, revised edition (1977), p.135, Ohm-sha Publishing (in Japanese).

Takahashi, K., Silicon carbide semiconductor element and its manufacturing method, Japanese patent disclosure H2011-3825 (2011) (in Japanese).

Tamamushi, B., Toyama, K., Kotani, M., Andou, E., Takahashi, H., Kubo, R., Nagakura, S. and Inoue, S., Encyclopedia for Physics and Chemistry 3rd edition (1981), p.1068, Iwanami Publishing (in Japanese).

Yonenaga, I., Taishi, T., Huang, X. and Hoshikawa, K., Dynamic characteristics of dislocations in Ge-doped and (Ge+B) codoped silicon, Journal of Applied Physics, Vol. 93, No. 1 (2003), pp.265-269. 